The Scenery of England and the Causes to which it is due was published in 1902, and the subject, beautifully illustrated, clearly expounded, and treated in an enthusiastic spirit, made the work so popular that it has reached a fifth edition.

In 1903 Lord Avebury gave to the Geological Society the results of "An Experiment in Mountain-building", based on apparatus which produced compression in two directions. The features thus produced on pieces of carpet-baize and alternating layers of sand were illustrated in his short published account of the phenomena.

He was elected a Fellow of the Geological Society in 1855, and in 1903 the Council awarded to him the first Prestwich Medal. He was elected a Fellow of the Royal Society in 1858, and became a Trustee of the British Museum in 1878, taking a warm interest in its affairs, and especially in the Natural History branch, afterwards established in South Kensington. He was chosen president of many societies representing diverse scientific and practical subjects, among them the Linnean, Royal Microscopical, Ray, Entomological, and Statistical Societies, and the Anthropological Institute. As the representative of many sciences he was fitly selected to preside over the jubilee meeting of the British Association held at York in 1881 .

Lord Avebury was twice married, his second wife being daughter of General Pitt-Rivers; F.R.S. He died at his seaside residence, Kingsgate Castle, near Margate, and was buried on May 31 at Farnborough churchyard, Kent. He is succeeded in the Peerage by the Hon, John Birkbeck Lubbock, his eldest son.

HERBERT KELSALL SLATER, F.G.S.

BORN AUGUST 28, 1875.

DIED MAY 2, 1913.

WE regret to record the death from snake-bite of Mr. Herbert Kelsall Slater, F.G.S., Assistant Geologist and Acting Second State Geologist to the Mysore Government. He was the son of the Rer. T. E. Slater, a well-known missionary in Mysore, and was educated at Bishop's Stortford College, Herts, and the Central College, Bangalore. In October, 1894, he joined the newly formed Mysore Geological Department under Mr. Bruce Foote, and afterwards served under his successors, Dr. J. W. Evans and Dr. W. F. Smeeth. He had already acquired a competent knowledge of geology in India when he returned to England in 1901 and studied at the Royal College of Science under Professor J. W. Judd. In 1909 he again visited this country for purposes of study, and afterwards spent some months in Canada and made himself familiar with its crystalline rocks, as these present many points of similarity to those on which he was working in India. He mapped a considerable portion of Mysore, especially in the Shimoga, Tarikere, and Kadur Districts, which lie in the north and west of the State, and brought an independent mind to the problems that presented themselves. His work will be found in the Records of the Mysore Geological Department. See vol. ii, pp. 118-30, 1899; vol. iii, pp. 148-62, 1901; vol. iv, pp. 119-46, 1903; vol. v, pt. ii, pp. 35-56, 1904 ; vol. vi, pt. ii, pp. 5-26, 1905 ('intrusive' and 'corrosive' 
quartz); vol. vii, pt. ii, pp. 1-20, 1906 (describing a remarkable conglomerate in the schists between Birur and Tarikere); vol. viii, pp. $3 \nmid-72,1907$ (iron-bearing rocks associated with charnockite); rol. ix, pp. 35-72, 1908 (banded magnetite quartzites). He also reported to the Government on various metalliferous deposits and building stones.

On the morning of his death, Mr. Slater was at a short distance from his camp near Tirthahalli, in the Shimoga District, when he trod upon a large snake, which coiled itself round his boot and bit him repeatedly under the knee through stout cord breeches. Death took place some twelve hours later. Mr. Slater leaves a widow and three young children. J. W. E.

\section{LESTER FRANK WARD, A.M., LL.D.}

WE learn from Nature that Dr. Lester Frank Ward, A.M., LL.D., Professor of Sociology at Brown University, Providence, R.I., and formerly Palæontologist of the U.S. Geological Survey, died in Washington on April 18, in his 72nd sear. He was born in 1841 at Joliet, Illinois, and was known to geologists more especially by his researches on the Flora of the Laramie Group, which he regarded as having equally Upper Cretaceous and Lower Tertiary affinities.

\section{ERNST ANTON LEOPOLD KITTL. \\ Born DeCember 2, 1854. DIED MAY 1, 1913.}

The death is announced of Professor Ernst Kittl, who was for many years associated with the geological and palæontological department of the Imperial Court Natural History Museum of Vienna, firt as assistant and ultimately as director. In 1885 he published two papers on the Lower Pliocene Mammalia of Maragha, Persia, and during subsequent years he prepared numerous other importunt papers on fossils, chiefly Mollusca. He also wrote a Guide Book to the Geology of the Salzkammergut, for the use of the International Geological Congress which met in Vienna in 1903.

\section{WILLIAM FOX, M. INST.C.E.}

WE regret to record the death on June 14, aged 66, of William Fox, M.Inst.C.E., M.Inst. Mech. E., an eminent waterworks engineer, whose labours naturally brought him into association with various geological problems. For many years he was a Fellow of the Geological Society, but had recently resigned.

\section{MISCFIIANEOUS.}

Mr. Charles Panzetta Cha'twin, of the Geological Department of the British Museum (Natural History), has been appointed Assistant Librarian to the Geological Society of London. Mr. Chatwin carries with him the cordial wishes of his friends, who feel that his many qualifications will in time allow hin to settle down into a long career of usefulness to the Fellows of the Society. 